УДК 597.552.51-154.343

\title{
В.И. Островский*
}

Хабаровский филиал Тихоокеанского научно-исследовательского рыбохозяйственного центра, 680028, г. Хабаровск, Амурский бульвар, 13а

\section{ТРАЕКТОРИИ МИГРАЦИЙ АМУРСКОЙ ГОРБУШИ ONCORHYNCHUS GORBUSCHA К РАЙОНАМ РАЗМНОЖЕНИЯ}

На основе анализа динамики уловов горбуши Oncorhynchus gorbuscha в различных районах Дальнего Востока в 1907-1986 гг. показано, что нарушения правильности чередования малочисленных и многочисленных поколений горбуши реже встречались в местах промысла, приближенных к местам воспроизводства, где в основном облавливались аборигенные группировки. Чаще такие нарушения встречались в местах вероятного прилова транзитных рыб. Наиболее сильно в данном отношении выделялись сахалинские и курильские районы. Анализ зависимости уловов амурской горбуши от уловов в сопредельных районах приводит к выводу о ее миграции к местам нереста из Охотского моря через районы промысла на северо-западном побережье Сахалина. Часть амурской горбуши вылавливается и в материковом прибрежье Сахалинского залива, но связь уловов в данном районе прослеживается лишь в четные годы при очень больших подходах амурских рыб. Показано, что рекордный улов горбуши на материковом прибрежье Сахалинского залива в 2015 г. не мог быть обеспечен ни аборигенной, ни амурской, ни сахалинской рыбой. Обсуждается гипотеза о ее принадлежности к группировкам Шантарского моря. Выдвинуто предположение о том, что рекордные уловы горбуши в Хабаровском крае в 2015 и 2016 гг., в дополнение к хорошей выживаемости в море, связаны с уменьшением ее доступности для промысла в Сахалино-Курильском регионе.

Ключевые слова: горбуша, Oncorhynchus gorbuscha, динамика численности, уловы, путь миграции.

Ostrovsky V.I. Pathways of the Amur pink salmon Oncorhynchus gorbuscha to the areas of reproduction // Izv. TINRO. — 2016. — Vol. 186. — P. 121-134.

Biannual sequence of high-numerous and low-numerous year-classes of pink salmon (Oncorhynchus gorbuscha) is disturbed rarely in the areas close to its spawning grounds where mostly local groupings are landed, as it is shown on the data of fishery statistics in many areas of Russian Far East for 1907-1986. The disturbances are related usually with by-catch of transitory fish, in particular for the Sakhalin-Kuril region. Dynamics of the pink salmon annual landings in the Amur correlates with its dynamics at northwestern Sakhalin, that allows to suppose the species migration from the Okhotsk Sea to its spawning grounds via northwestern Sakhalin. Besides, a part of the Amur pink is caught at the mainland coast of the Gulf of Sakhalin, but the landings in the Amur correlate well with this transitory area in even years only, when the run is stronger. The highest catches of pink salmon on the mainland coast of the Gulf of Sakhalin in 2015 could be ensured neither the Amur nor the Sakhalin groupings; a hypothesis on the Shantar groupings contribution is discussed. In general, high catches of pink salmon in Khabarovsk Region in 2015-2016 are possibly reasoned by its good survival and lowered fishery in the Sakhalin-Kuril region.

* Островский Владимир Иванович, кандидат биологических наук, начальник отдела, e-mail: ostrovkhv@rambler.ru.

Ostrovsky Vladimir I.,Ph.D., head of department, e-mail: ostrovkhv@rambler.ru. 
Key words: pink salmon, Oncorhynchus gorbuscha, abundance dynamics, catch, pathway.

\section{Введение}

Горбуша Oncorhynchus gorbuscha — наиболее сложный для прогнозирования вид тихоокеанских лососей. Одна из причин больших ошибок прогнозов нерестовых подходов данного вида связана с тем, что на пути нерестовой миграции одна и та же популяция может подвергаться неоднократному облову. Это искажает данные о реальном соотношении численности родителей и потомков не только в конечных пунктах учета, но и в промежуточных, в которых облавливается рыба смешанного происхождения.

В отношении путей миграции амурской горбуши единого мнения нет. Подробный обзор представлений по данному вопросу приведен в работе Г.В. Новомодного (2003). Обзор можно кратко обобщить так: амурская горбуша нагуливается в Охотском и Японском морях, а также в Тихом океане, на нерест возвращается либо с юга через Татарский пролив, либо с севера через Сахалинский залив, либо обоими путями. Автор обзора на основе исследования сроков, направления миграций молоди, ее биологических характеристик и анализа течений полагает, что амурская горбуша возвращается на нерест тем же путем, которым она мигрировала в море - через Сахалинский залив. Цель нашей работы - попытаться найти ответ на данный вопрос на основе анализа статистики уловов.

\section{Материалы и методы}

В работе использованы сведения по вылову горбуши в 1937-1956 гг. в 11 пунктах лова, расположенных в русле Амура, Амурском лимане и прилегающих акваториях (рис. 1, таблица), из научного отчета Н.П. Беспалова (1957a, б). На рисунках и в тексте приведены сокращенные названия мест лова, в таблице - полные.

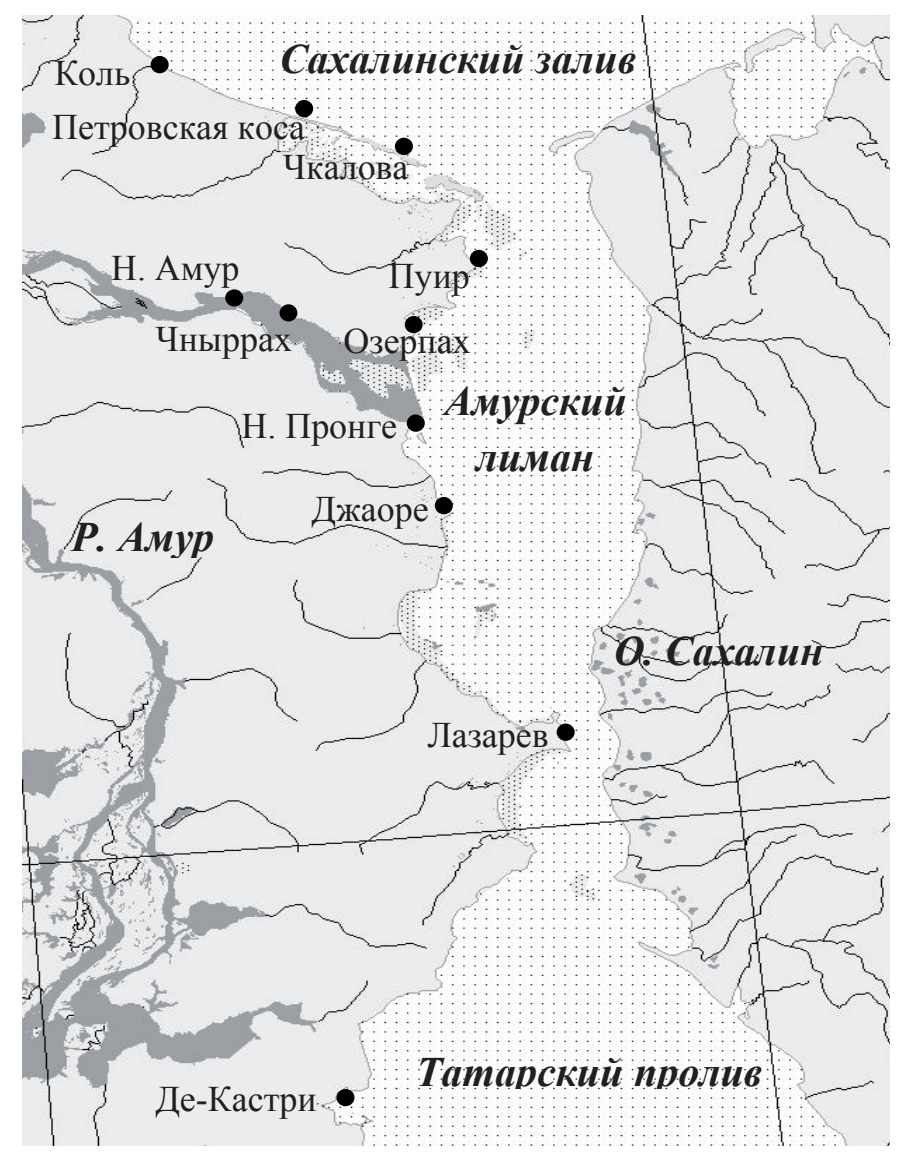

Рис. 1. Карта-схема мест лова горбуши

Fig. 1. Scheme of the pink salmon catch sites 
Районы лова горбуши и ее уловы в 1937-1956 гг.

Areas and sites of pink salmon fishery and the landings in 1937-1956

\begin{tabular}{|c|c|c|c|c|}
\hline Район & Место лова & $\begin{array}{c}\text { Число } \\
\text { лет }\end{array}$ & $\begin{array}{c}\text { Средний } \\
\text { улов, т }\end{array}$ & $\begin{array}{c}\text { Стандартное } \\
\text { отклонение, т }\end{array}$ \\
\hline \multirow{2}{*}{ Русло Амура } & Нижне-Амурский ГРТ & 20 & 283,0 & 296,8 \\
\hline & P/з Чныррах & 18 & 23,5 & 36,7 \\
\hline \multirow{4}{*}{ Амурский лиман } & P/з Пуир & 15 & 14,3 & 19,7 \\
\hline & Р/к Озерпах & 18 & 26,4 & 40,7 \\
\hline & Нижнее Пронге & 18 & 73,9 & 80,5 \\
\hline & P/3 Джаоре & 11 & 80,0 & 87,3 \\
\hline \multirow{3}{*}{ Сахалинский залив } & Р/к им. Чкалова & 10 & 7,3 & 9,0 \\
\hline & Р/з Петровская коса & 11 & 8,6 & 10,4 \\
\hline & P/3 Коль & 19 & 10,7 & 9,0 \\
\hline Прол. Невельского & Р/з мыс Лазарев & 18 & 14,2 & 10,8 \\
\hline Татарский пролив & Р/к Де-Кастри & 20 & 33,0 & 24,9 \\
\hline \multirow{4}{*}{ Сахалин } & Зал. Анива* & 16 & 1700,0 & 2055,2 \\
\hline & Юго-восточный район* & 16 & 8192,5 & 8665,7 \\
\hline & Юго-западный* & 19 & 4105,3 & 3833,9 \\
\hline & Северо-западный* & 20 & 1362,5 & 1396,4 \\
\hline \multicolumn{2}{|l|}{ Приморье* } & 20 & 3073,2 & 2384,2 \\
\hline \multicolumn{2}{|l|}{ Южно-Курильская подзона* } & 19 & 3547,9 & 3302,7 \\
\hline \multicolumn{2}{|l|}{ Охотский район* } & 20 & 5599,0 & 4871,7 \\
\hline \multicolumn{2}{|l|}{ Магаданская область* } & 20 & 3597,0 & 2742,1 \\
\hline \multicolumn{2}{|c|}{ Западно-Камчатская подзона* } & 20 & 49608,0 & 27807,2 \\
\hline \multicolumn{2}{|c|}{ Восточно-Камчатская подзона* } & 20 & 9148,5 & 5285,8 \\
\hline
\end{tabular}

* По Н.В. Яновской с соавторами (1989).

Для сравнения использованы данные по вылову горбуши в некоторых отдаленных от Амура местах лова за эти же годы, опубликованные Н.В. Яновской с соавторами (1989), а также из иных источников, упоминаемых в тексте.

Статистика уловов в сравниваемых районах слишком различается как по степени агрегации популяционных группировок, так и по объемам вылова, поэтому кластерный анализ проводили по стандартизованным отклонениям от среднемноголетних значений.

\section{Результаты и их обсуждение}

Согласно результатам кластерного анализа (рис. 2) из всех наблюдений наиболее сильно выделяется компактная ветвь амурских группировок (русловых и лиманных). Из них более сходной была динамика вылова в русле Амура (Нижне-Амурский, Чныррах, см. рис. 1). С уловами в данных пунктах более тесно связаны уловы в южных лиманных пунктах (Пронге, Джаоре), менее тесно - в северных лиманных пунктах (Озерпах, Пуир). Случайно или нет, уловы амурских группировок коррелируют с уловами в районе Петровской косы (Сахалинский залив).

Остальные группировки по уловам делятся на два больших кластера. Первый включает преимущественно северные группировки Охотского моря. Он делится на северную часть (Магадан, Охотск, Камчатка) и южную, включающую некоторые группировки Сахалина, Курильских островов и материкового побережья Сахалинского залива. Второй кластер включает южные группировки Сахалина и группировки материкового побережья Японского моря.

На основе кластерного анализа явных связей уловов амурской горбуши с уловами в сопредельных районах промысла за пределами Амурского лимана не выявлено, поэтому для ответа на вопрос о возможных путях миграции амурской горбуши к Амурскому лиману рассмотрим дополнительные критерии.

В связи с упрощенным возрастным составом горбуши поколения четных лет практически полностью изолированы от поколений нечетных лет. Различия в числен- 
Tree Diagram for 21 Variables

Complete Linkage

1-Pearson $r$

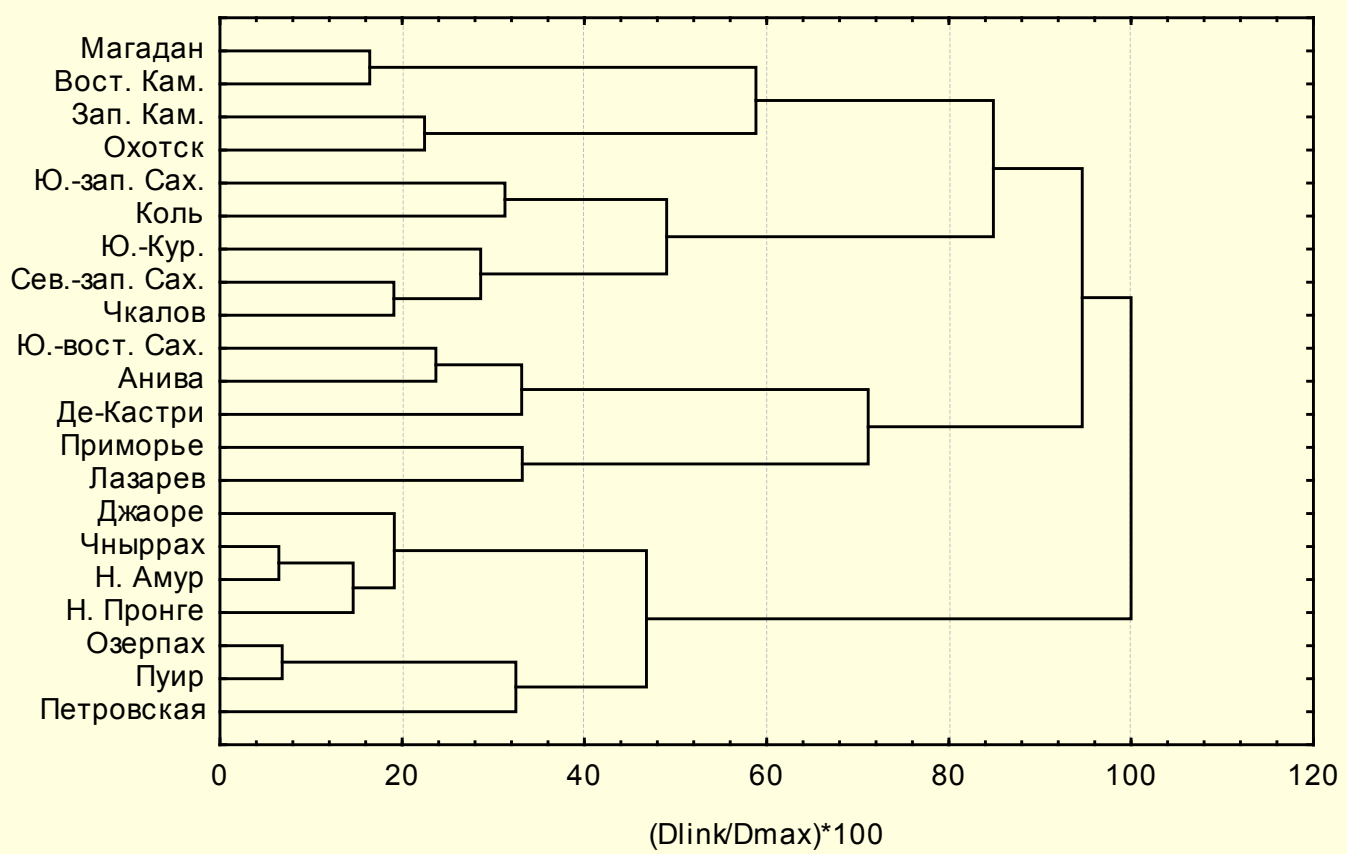

Рис. 2. Дендрограмма динамики уловов горбуши в 1937-1956 гг.

Fig. 2. Tree diagram for dynamics of the pink salmon landings by fishing grounds in 1937-1956

ности поколений в сочетании с их временной изоляцией порождают наиболее известное свойство динамики - относительно правильное чередование малочисленных и многочисленных поколений. В случае численного доминирования поколений четных лет разность улова четного года с уловом предшествующего, нечетного, года положительная (прирост положительный), в случае доминирования поколений нечетных лет - отрицательная.

Интегральную характеристику «правильности» чередования поколений четных или нечетных лет можно выразить как долю четных лет, в которых прирост улова положительный, от общего числа четных лет (рис. 3). При значении данного критерия, равном 1, в 100 \% наблюдений численно доминируют поколения четных лет, при его значении, равном 0, - поколения нечетных лет. В период 1937-1956 гг. численность горбуши варьировала либо по «амурскому» типу с доминированием поколений четных лет (рис. 3, правый овал), либо по «охотскому» типу — с дефицитом рыб данных поколений.

Судя по наличию группировок со значением рассматриваемого показателя, отличным от 0 или 1 , порядок чередования численного преобладания поколений не стабилен во времени, поэтому желательно определить его на рядах большей длительности. Для этого использовали сведения по уловам горбуши, приведенные в справочнике Н.В. Яновской с соавторами (1989). Они не столь детализованы по районам лова, но временные ряды более продолжительные, в различных группировках от 51 до 77 лет.

Анализ рядов большей длительности свидетельствует о том, что абсолютно правильные чередования урожайности поколений четных и нечетных лет не свойственны ни одной из рассмотренных группировок. Однако изменчивость урожайности поколений преимущественно по «амурскому» (частота более 50 \%, рис. 4) или «охотскому» (менее $50 \%$ ) типу выявляется на тех же группировках, что и при анализе коротких рядов (см. рис. 3). Деление по типам динамики условно, оно характеризует порядок 


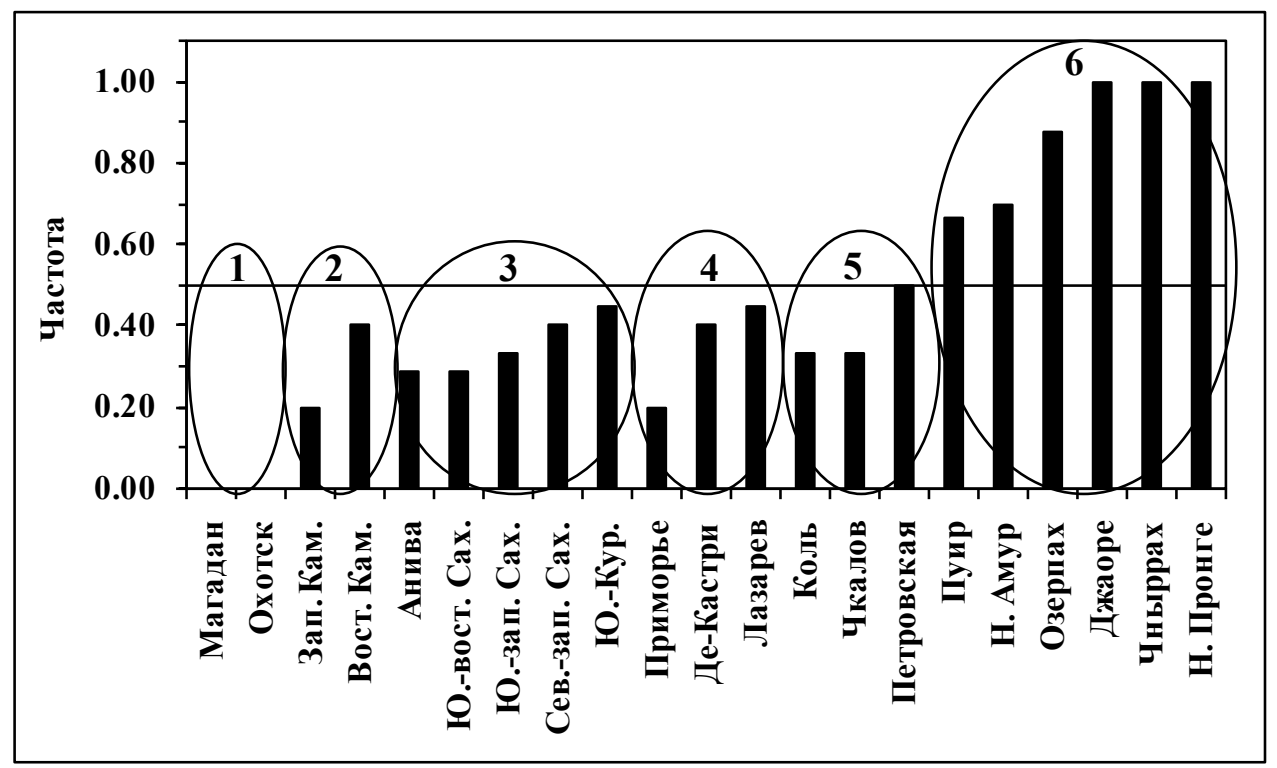

Рис. 3. Частота встречаемости положительных приростов улова горбуши по четным годам в 1937-1956 гг. Выделены группировки: 1 - североохотоморские, 2 - камчатские, 3 - сахалино-курильские, 4 - япономорские, 5- Сахалинского залива, 6 - Амура и Амурского лимана

Fig. 3. Frequency of the pink salmon catch increments (positive only) in even years of the period 1937-1956. The groupings are shown: 1 - North Okhotsk; 2 - Kamchatka; 3 - Sakhalin-Kuril; 4 - Japan Sea; 5 - Gulf of Sakhalin; 6- the Amur with its estuary

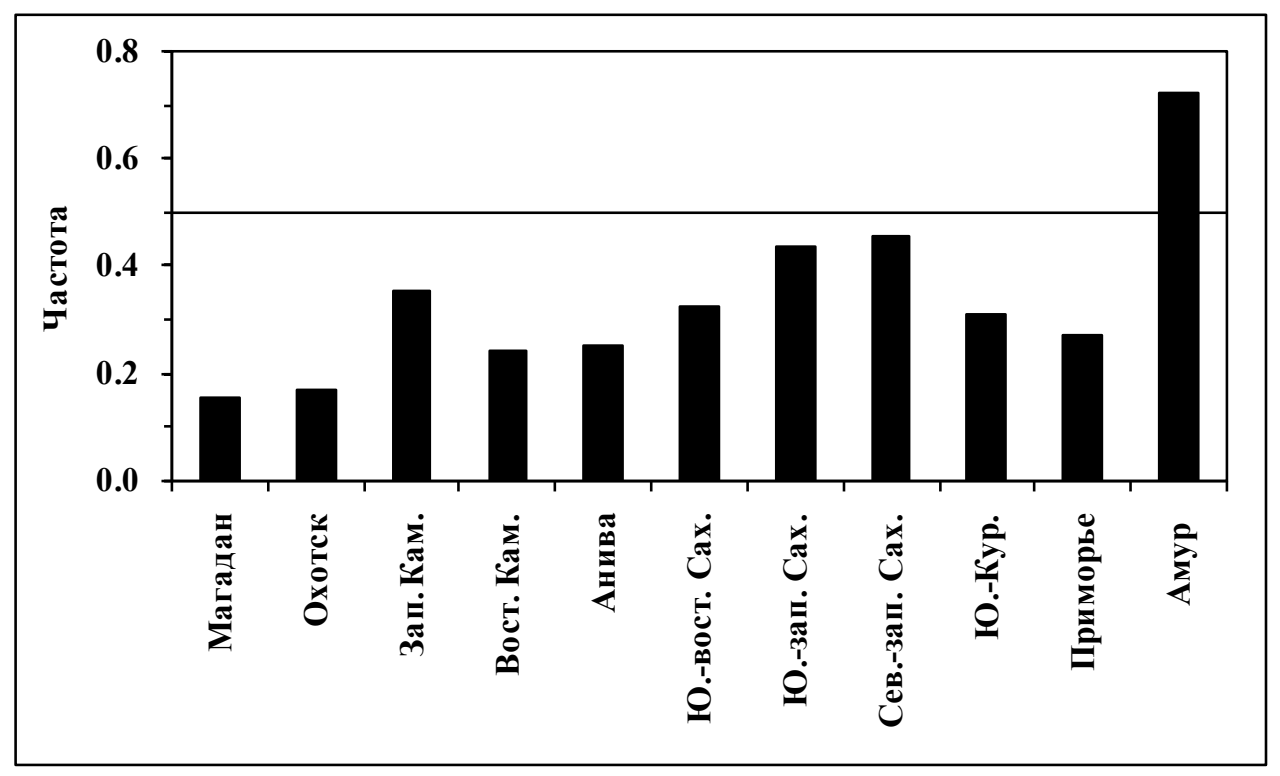

Рис. 4. Частота встречаемости положительных приростов улова горбуши по четным годам в 1907-1986 гг.

Fig. 4. Frequency of the pink salmon catch increments (positive only) in even years of the period 1907-1986

чередования урожайных и неурожайных поколений за конкретный период: например, начиная с 1996 г. по настоящее время урожайность приморской группировки чередуется по «амурскому» типу.

Одна из причин временной изменчивости рассматриваемого свойства динамики — наличие сборок, когда правильное чередование положительных и отрицательных 
приростов улова сменяется серией однонаправленных приростов. Так, например, в 1926-1936 гг. в Охотском районе доминировала горбуша четных лет (рис. 5), но в 1937 г. улов оказался не меньше, а больше, чем в предшествующем, соответственно 2 года подряд приросты были положительными (положительная сборка). С 1938 по 1940 г. уловы уменьшались, приросты 3 года подряд были отрицательными (отрицательная сборка). С 1941 г. (на рис. 5 выделен) положительные приросты наблюдались только в нечетные годы.

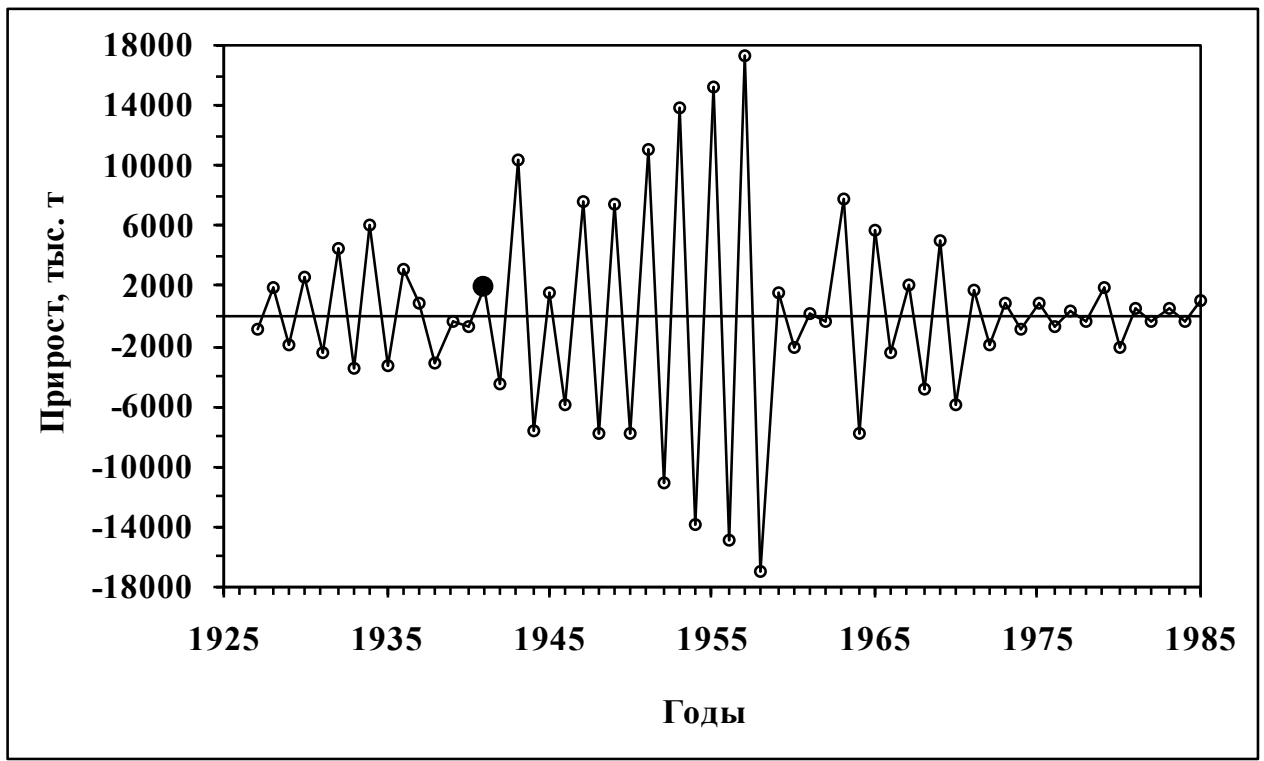

Рис. 5. Динамика разности уловов охотской горбуши четного и предшествующего нечетного года (прирост)

Fig. 5. Dynamics of the Okhotsk pink salmon annual catch increments for the year-classes of even years

В период 1907-1986 гг. наибольшее число сборок (от 9 до 16) наблюдалось в сахалино-курильских группировках. Помимо разного числа сборок в различных группировках, сборки различались по длительности. Например, у охотской горбуши в сумме они длились 5 лет, доля лет в сборках от общего числа наблюдений (60 лет) составляла 0,083 . В остальных группировках данный показатель больше, но лишь у сахалино-курильских он превышал 0,3 (рис. 6). Наибольшее значение данного показателя отмечено у южнокурильской группировки горбуши, у которой на 77 лет наблюдений приходилось 40 лет в сборках.

Если сборки возникают случайно, у одной и той же группировки число положительных сборок, вероятно, должно уравновешиваться числом отрицательных сборок. У охотской группировки, например, одна из двух сборок положительная (см. рис. 5), соответственно частота положительных сборок составляет 0,5 . Близкое к такому соотношение положительных и отрицательных сборок наблюдалось практически везде, за исключением Сахалино-Курильского региона, в котором преобладали отрицательные сборки (рис. 7).

Вторая причина нарушения правильности чередования малочисленных и многочисленных поколений - реверсия доминирования, когда после сборки малочисленное поколение становится многочисленным и наоборот. Не все сборки приводят к смене доминирования: например, ни одна из 6 сборок магаданской группировки горбуши не привела к реверсии. В итоге, хотя чередование поколений высокой и низкой численности не было абсолютно правильным (см. рис. 4), весь период наблюдений (51 год) в данной группировке численно доминировали поколения нечетных лет. 


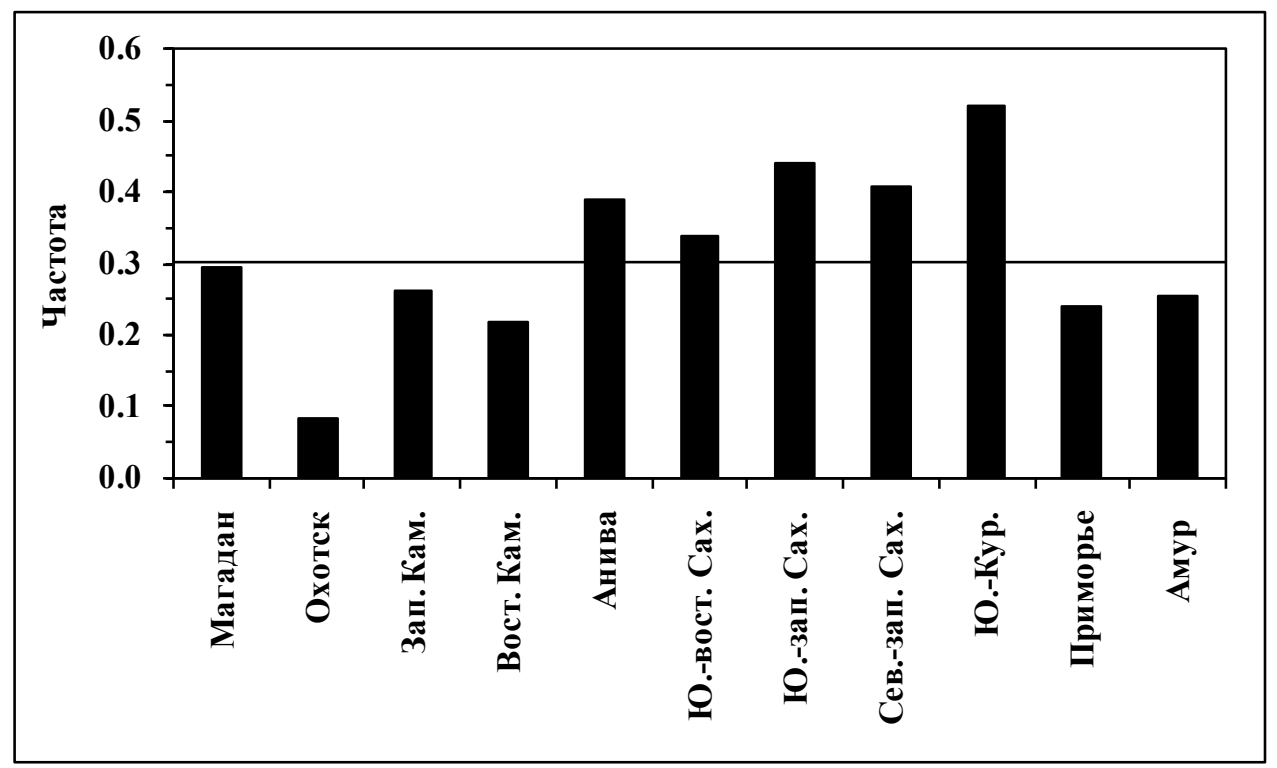

Рис. 6. Доля лет в сборках в 1907-1986 гг.

Fig. 6. Portion of the years with disturbance of biannual sequence of high-numerous and low-numerous year-classes of pink salmon in the period 1907-1986, by regions. See explanations in the text

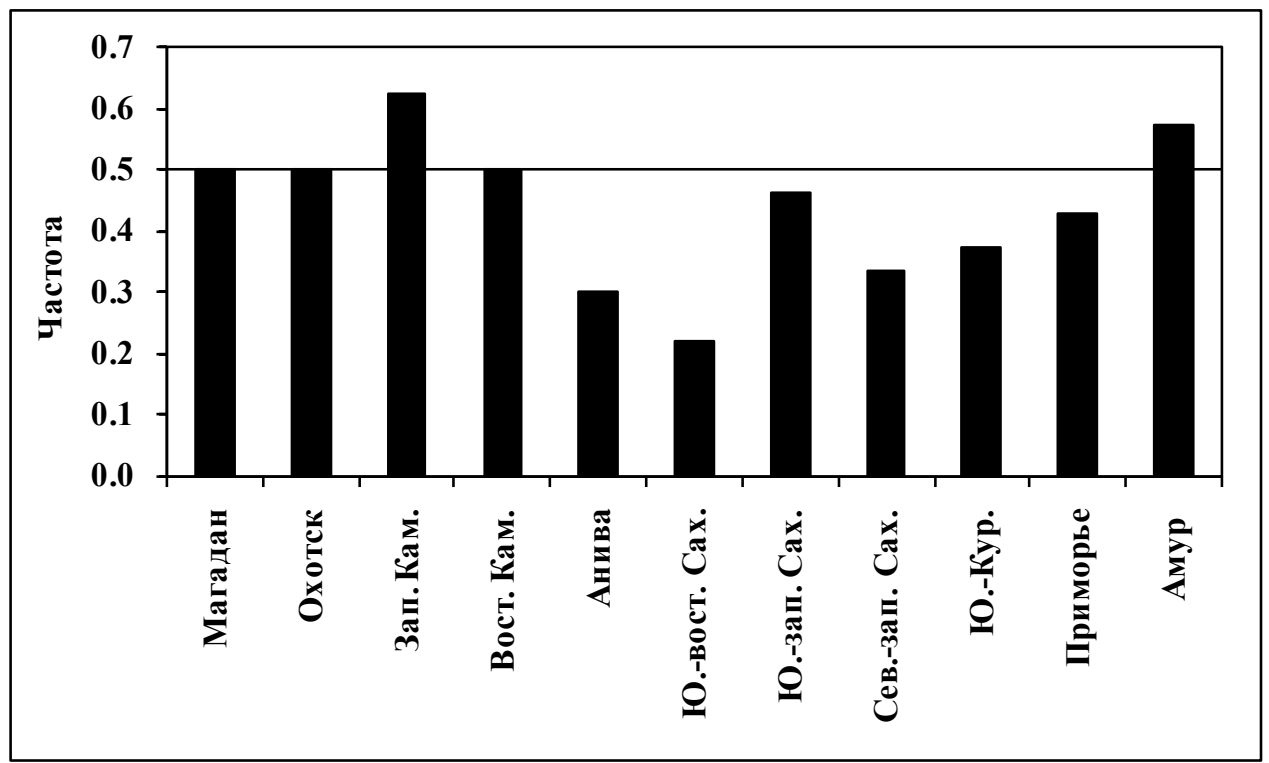

Рис. 7. Частота встречаемости положительных сборок от их общего числа в 1907-1986 гг.

Fig. 7. Portion of the years with disturbance of biannual sequence of high-numerous and low-numerous year-classes of pink salmon toward positive annual increment relative to their total number in the period 1907-1986, by regions. See explanations in the text

Дважды смена доминирования наблюдалась у амурской горбуши (доминировали четные - нечетные - четные), столько же, но в противоположной последовательности - у охотской и западнокамчатской горбуши (рис. 8). Наиболее часто реверсия доминирования происходила у сахалино-курильских группировок, за исключением группировки юго-восточного Сахалина, хотя сборки в ней происходили 9 раз и по суммарной длительности занимали 25 лет из 74 лет наблюдений (около 34 \% от всех наблюдений, см. рис. 6). 


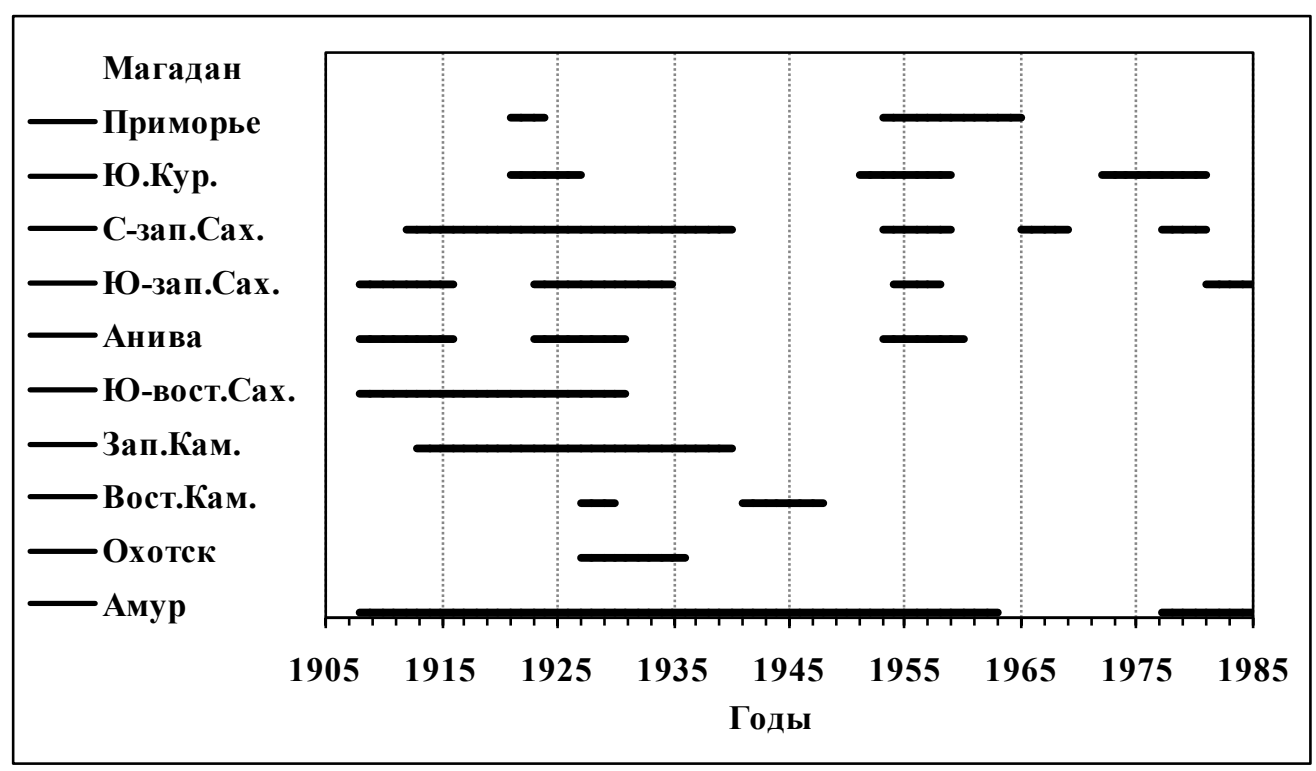

Рис. 8. Сроки численного доминирования поколений горбуши четных лет

Fig. 8. Periods of the pink salmon year-classes of even years domination in number, by regions

Вполне вероятно, что синфазность или противофазность доминирования уловов горбуши различных группировок (см. рис. 8) отражается на изменчивости масштабов ее уловов в регионе, но рассмотрение данного вопроса не входит в цель нашей работы.

Как и у прочих группировок с «охотским» типом динамики, у группировки северо-западного Сахалина в четные годы чаще наблюдались отрицательные приросты уловов (см. рис. 4). Однако в отличие от прочих группировок «охотского» типа динамики уловы данной группировки в четные годы в среднем почти вдвое превосходили уловы в нечетные годы (рис. 9).

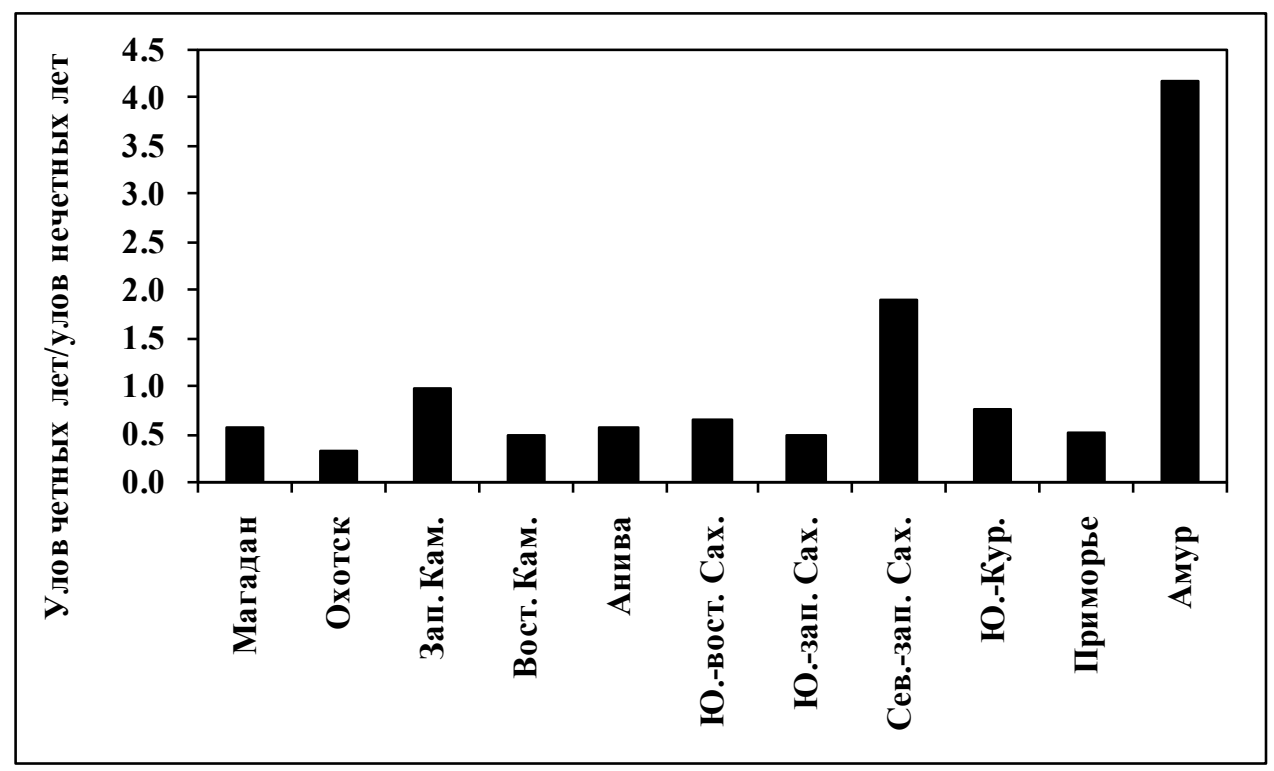

Рис. 9. Отношение средних уловов четных лет к средним уловам нечетных лет в 1907-1986 гг.

Fig. 9. Ratio of the pink salmon mean catch in even years to the mean catch in odd years for the period 1907-1986, by regions 
Корректное применение корреляционного анализа, на основе которого построена дендрограмма (см. рис. 2), предполагает наличие линейных связей уловов сравниваемых районов. Миграция рыб конкретной группировки через несколько промысловых районов, возможные вариации трасс миграции, отсутствие постоянства степени эксплуатации и другие причины могут отражаться на тесноте связи уловов сравниваемых районов и, соответственно, на представлении о вероятных путях миграции рыб на основе использованного нами варианта кластерного анализа.

Таким образом, обращая внимание на корреляционные связи уловов, не следует придавать им слишком большое значение. Хотя, бесспорно, большее сходство динамик близкорасположенных участков лова по сравнению с отдаленными участками (см. рис. $1,2)$, а также группирование районов лова по широтному принципу свидетельствуют о том, что данный метод приемлем в качестве одного из ориентиров для формирования гипотез относительно путей миграции горбуши.

Второй ориентир - характер динамики уловов. Обратим внимание на следующее ее свойство: чем ближе рыбы конкретной группировки вылавливаются к конечному району нерестовой миграции, тем более упорядоченно чередование уловов четных и нечетных лет. Так, в подавляющем большинстве лет положительные приросты численности горбуши магаданской группировки наблюдались в нечетные годы (см. рис. $3,4)$, сборки наблюдались редко, не были продолжительными (см. рис. 6), возникали случайно (см. рис. 7) и не приводили к реверсии доминирования (см. рис. 8). Близкими свойствами обладают охотская, обе камчатские и приморская группировки. По всем этим критериям, за исключением противофазной динамики уловов (доминирования преимущественно по четным годам), к ним близка амурская группировка.

Данный результат позволяет предположить, что бо́льшая часть нарушений правильности чередования уловов четных и нечетных лет не характерна для самостоятельно воспроизводящихся группировок. Вероятно, нарушения в основном обусловлены выловом рыб различных популяций, обладающих собственной динамикой численности, совместно мигрирующих через районы промысла. Вполне очевидно, что такие нарушения могут проявляться лишь в случае значительного прилова транзитной рыбы, в особенности противофазной динамики.

В отношении нарушений правильности чередования уловов четных и нечетных лет наиболее сильно выделяются сахалино-курильские группировки. Вряд ли данный эффект связан с рыборазводной деятельностью, поскольку он выявляется и в районе северо-западного Сахалина, где мигрирует горбуша естественного воспроизводства.

Соответственно рассмотренным ориентирам и гипотезам можно предположить, что динамика камчатских уловов горбуши не случайно связана с охотскими и магаданскими (см. рис. 2), уловы группировок Де-Кастри, Лазарев, Приморье - с уловами южной части Сахалина (Анива, юго-восточный Сахалин). Также можно предположить, что пути миграции горбуши в Сахалинский залив (группировки Коль, Чкалов) проходят близ южнокурильского района, далее близ северо-западных районов промысла о. Сахалин. Но откуда мигрирует амурская горбуша? Столь мощная группировка не может не влиять на уловы в промежуточных пунктах лова на путях миграции. Согласно результатам кластерного анализа можно предположить, что в русло Амура горбуша мигрирует как с южной прилегающей акватории лимана (Пронге, Джаоре), так и с северной (Пуир, Озерпах). Однако уловы данных группировок корреляционно не связаны с уловами на северном (группировка Чкалов) и южном (группировка Лазарев) входах в Амурский лиман (см. рис. 1, 2). Более того, уловы этих группировок были слишком малы (см. таблицу) и в целом противофазны (см. рис. 3) уловам амурской и лиманной горбуши.

Наибольшие уловы из районов, прилегающих к местам промысла амурской и лиманной группировок, наблюдались в районе северо-западного Сахалина (см. таблицу). О большой вероятности прилова амурской горбуши в данном районе косвенно свидетельствует наибольшая по сравнению с другими группировками «охотского» типа частота положительных приростов улова по четным годам (см. рис. 4), характерных 
для амурских группировок. Этому району также свойственны частые длительные сборки (см. рис. 6), частые реверсии циклов доминирования (см. рис. 8). Согласно нашей гипотезе эти признаки характерны для вылова рыб смешанного происхождения.

Сам факт вдвое большего вылова горбуши в данном районе по обычно неурожайным для Сахалина четным годам по сравнению с выловом в урожайные нечетные годы (см. рис. 9) и близость мощной противофазной группировки амурской горбуши подтверждают гипотезу о прилове в данном районе транзитной рыбы.

Динамика вылова горбуши в Амуре тесно связана с динамикой вылова в Амурском лимане (см. рис. 2), что не удивительно, поскольку большую часть лиманных уловов составляют амурские рыбы. Следовательно, можно предположить, что до входа в лиман рыбы данных группировок мигрируют по одним и тем же трассам. В таком случае в районе северо-западного Сахалина должны облавливаться и амурские, и лиманные группировки, а их суммарный вылов должен зависеть от вылова на острове. Для проверки данной гипотезы использованы сведения по уловам амурской горбуши с учетом вылова в районе материковой части Амурского лимана (Енютина, 1972).

Судя по результатам регрессионного анализа (рис. 10) как по четным, так и по нечетным годам сахалинские промыслы явно конкурировали с амурскими: избыточный вылов горбуши на Сахалине заметно уменьшал вылов в Амуре и Амурском лимане. Несмотря на больший средний вылов горбуши в районе северо-западного Сахалина по четным годам (см. рис. 9), конкуренция с амурскими промыслами сильнее выражена в нечетные годы, когда амурской горбуши относительно мало. В среднем в нечетные годы вылов горбуши в рассматриваемом районе Сахалина составлял около 58 \% от вылова в Амуре и лимане, в четные - около $20 \%$.
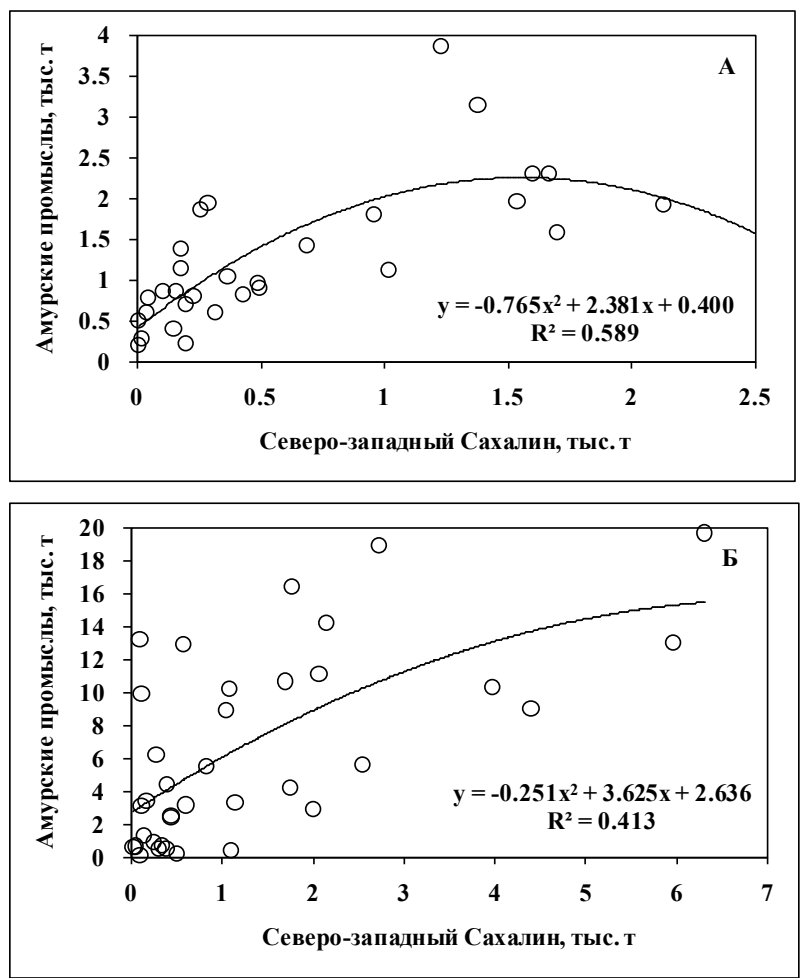

Рис. 10. Зависимость уловов горбуши на амурских промыслах от ее уловов в районе северо-западного Сахалина в 1915-1986 гг.: А - нечетные годы, Б - четные годы

Fig. 10. Relationship between the pink salmon annual landings $\left(10^{3} \mathrm{t}\right)$ in the Amur and at northwestern Sakhalin for 1915-1986: A — odd years, $\mathbf{6}$ even years

Судя по разбросу точек (см. рис. 10), при малом вылове горбуши в Амуре и материковой части Амурского лимана вылов на Сахалине всегда мал, при большом вылове, особенно в четные годы, он может быть и большим и малым. Следовательно, возможность хорошего улова транзитной амурской горбуши на Сахалине не всегда реализуется, например, в силу непостоянства трасс ее миграции. Именно большими уловами транзитной рыбы по некоторым неурожайным для сахалинских группировок четным годам можно объяснить уменьшение уловов в последующие годы, что и 
приводит к формированию и численному преобладанию отрицательных сборок над положительными (см. рис. 7).

Предположим, что в неурожайные для амурской горбуши нечетные годы на северо-западном Сахалине вылавливалась исключительно рыба островного происхождения. Ее улов в эти годы в среднем составлял 0,7 тыс. т. Уловы прочих сахалинских группировок в нечетные годы примерно вдвое превышали уловы четных лет (см. рис. 9). Если динамика численности аборигенной горбуши северо-западного Сахалина не представляет исключения из всех группировок с «охотским» типом динамики, ее вылов здесь по неурожайным для Сахалина четным годам должен составлять приблизительно половину от вылова в нечетные годы, т.е. порядка 0,35 тыс. т. Но по четным годам здесь вылавливалось в среднем 1,30 тыс. т, т.е. вероятно, аборигенная рыба в улове составляла порядка 27 \%. Соответственно, около 73 \% улова четных лет должна была составлять транзитная горбуша материковых рек.

Близкий результат получается при сравнении уловов в интересующих нас районах без подразделения на четные и нечетные годы. Зависимость уловов в районе северо-западного Сахалина от уловов амурских промыслов (тыс. т) можно описать уравнением: улов на Сахалине $=0,176( \pm 0,025) \times$ улов в Амуре и лимане $+0,314( \pm 0,161) ;\left(\mathrm{R}^{2}=\right.$ $=0,43 ; \mathrm{F}=49,0 ; \mathrm{P}<0,01)$. Согласно уравнению, при улове амурской горбуши, равном 0 , улов аборигенной островной горбуши в районе северо-западного Сахалина в среднем составляет 0,314 тыс. т, т.е. порядка $30 \%$ от фактического среднего вылова в этом районе $(1,04$ тыс. т). В это же время горбуши амурской группировки вылавливалось в среднем 4,12 тыс. т, соответственно, вылов аборигенной горбуши северо-западного Сахалина в среднем составлял около 7,6 \% от вылова на амурских и лиманных промыслах.

Таким образом, несомненно, амурская горбуша попадает в Амурский лиман, мигрируя вдоль островного прибрежья Сахалинского залива, по-видимому, большая часть рыб приближается к материку южнее устья Амура (Пронге, Джаоре), меньшая - севернее (Озерпах, Пуир) (см. рис. 1, 2), но проходит ли северный поток через материковые районы промысла в Сахалинском заливе? В прошлом веке вылов горбуши здесь не превышал 600 т. В 2015 г. ее выловлено более 11 тыс. т, что близко к лучшим результатам промысла в Охотском районе, нерестовый фонд которого на порядок больше, чем в реках залива. Следовательно, гипотеза о том, что рекордный улов в заливе обеспечен аборигенной рыбой, должна быть отвергнута. Этот вывод не противоречит предварительному прогнозу запаса горбуши данного района на 2015 г., разработанному сотрудниками лаборатории тихоокеанских лососей ХфТИНРО-центра, основанному на данных о численности покатной молоди и среднемноголетнем коэффициенте возврата (запас - 3,6 тыс. т, ВВ - 2,6 тыс. т).

Коллегиальным решением Ученого совета прогноз было рекомендовано переработать с учетом тенденций изменения уловов в последние годы. Прогноз переработали (запас - 10,1 тыс. т, ВВ - 9,1 тыс. т, в ходе промысла скорректированы в большую сторону), но так как разработчики прогноза не были уверены ни в объективности промысловой статистики (Канзепарова и др., 2013), ни в чрезмерно высоком потенциале воспроизводства местной горбуши, увеличение ВВ обосновали гипотезой о возможном прилове амурской горбуши, мигрирующей через Сахалинский залив.

Таким образом, рассмотрим вторую гипотезу - о прилове в Сахалинском заливе амурской горбуши. С одной стороны, динамика вылова горбуши группировок Чкалов и Коль Сахалинского залива не коррелирует с динамикой вылова амурской горбуши, с другой - группировка Петровской косы (Сахалинский залив) объединяется в один кластер с амурской горбушей (рис. 2), поэтому полностью отрицать данную гипотезу нельзя. Для ее проверки сравним уловы горбуши в Сахалинском заливе, неполная статистика которых ведется с 1938 г., с уловами амурской горбуши (Енютина, 1972), дополнив ряды данными последних лет. Как оказалось, связь уловов амурской горбуши с уловами в Сахалинском заливе становится заметной лишь при вылове в первом более 9 тыс. т (рис. 11), но в нечетные годы вылов амурской группировки не достигает таких значений. 


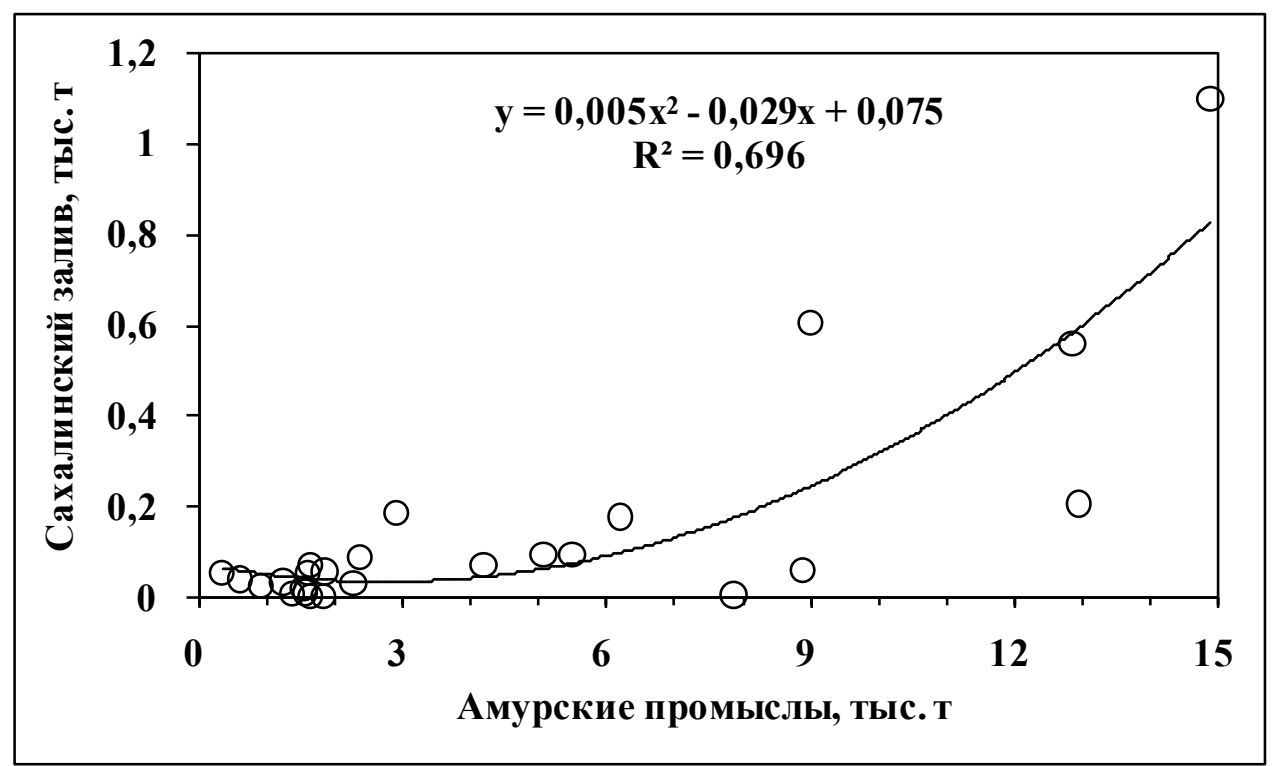

Рис. 11. Зависимость вылова горбуши в Сахалинском заливе от вылова в лимане и русле Амура в четные годы 1938-2014 гг.

Fig. 11. Relationship between the pink salmon annual landings $\left(10^{3} \mathrm{t}\right)$ in the Gulf of Sakhalin and the Amur with its estuary for even years of 1938-2014

Путина 2015 г. не была исключением: как обычно для нечетных лет, прогноз запаса амурской горбуши, фактический подход и вылов не были большими, ВВ, близкий к $50 \%$ запаса, составил лишь около 2,3 тыс. т, выловлено около 1,8 тыс. т. Таким образом, даже если бы в Сахалинском заливе в 2015 г. была выловлена вся амурская горбуша вместе со всей аборигенной, вылов не мог бы достичь 11 тыс. т.

Рекордный вылов горбуши близ материкового прибрежья Сахалинского залива по времени совпал с катастрофическим недоловом на Сахалине, поэтому уместна третья гипотеза: высокий улов обеспечен случайной миграцией части сахалинской горбуши к рекам материка. С одной стороны, количество горбуши, выловленной в Сахалинском заливе, было многократно меньше недолова на Сахалине, но, с другой стороны, не исключено, что основная часть эмигрантов прошла на север, в слабо охваченный рыбными промыслами Тугуро-Чумиканский район (Шантарское море). По крайней мере, по оценке сотрудников лаборатории тихоокеанских лососей ХфТИНРО-центра, в 2015 г. в данном районе подход к рекам в 7,5 раза превысил прогнозное значение.

Гипотезе об островном происхождении горбуши из уловов близ материкового побережья Сахалинского залива в 2015 г. противоречит то, что уловы в данном районе по урожайным для него нечетным годам начали увеличиваться еще с 2007 г. В настоящее время они противофазны, но по масштабам близки к вылову в Амуре (рис. 12).

Отвержение гипотез об аборигенном, амурском или островном происхождении горбуши, выловленной в 2015 г. в Сахалинском заливе, а также «избыточный» подход ее в Тугуро-Чумиканский район позволяют предположить, что она происходит из рек данного района. Нерестовый фонд этих рек соизмерим с нерестовым фондом Охотского района, но численность горбуши в них многократно меньше. Традиционно «негорбушовыми» считаются именно реки района, хотя рационального объяснения этому явлению нет.

Ослабленный домашний инстинкт горбуши как гомеостатическая компенсация предельно упрощенной возрастной структуры должен сочетаться с пониженной по сравнению с другими тихоокеанскими лососями требовательностью к условиям на нерестилищах. Действительно, она легко осваивает практически все сколько-нибудь пригодные для воспроизводства реки, поэтому обычно низкая численность горбуши в реках Шантарского моря вряд ли связана с условиями в местах нереста. 


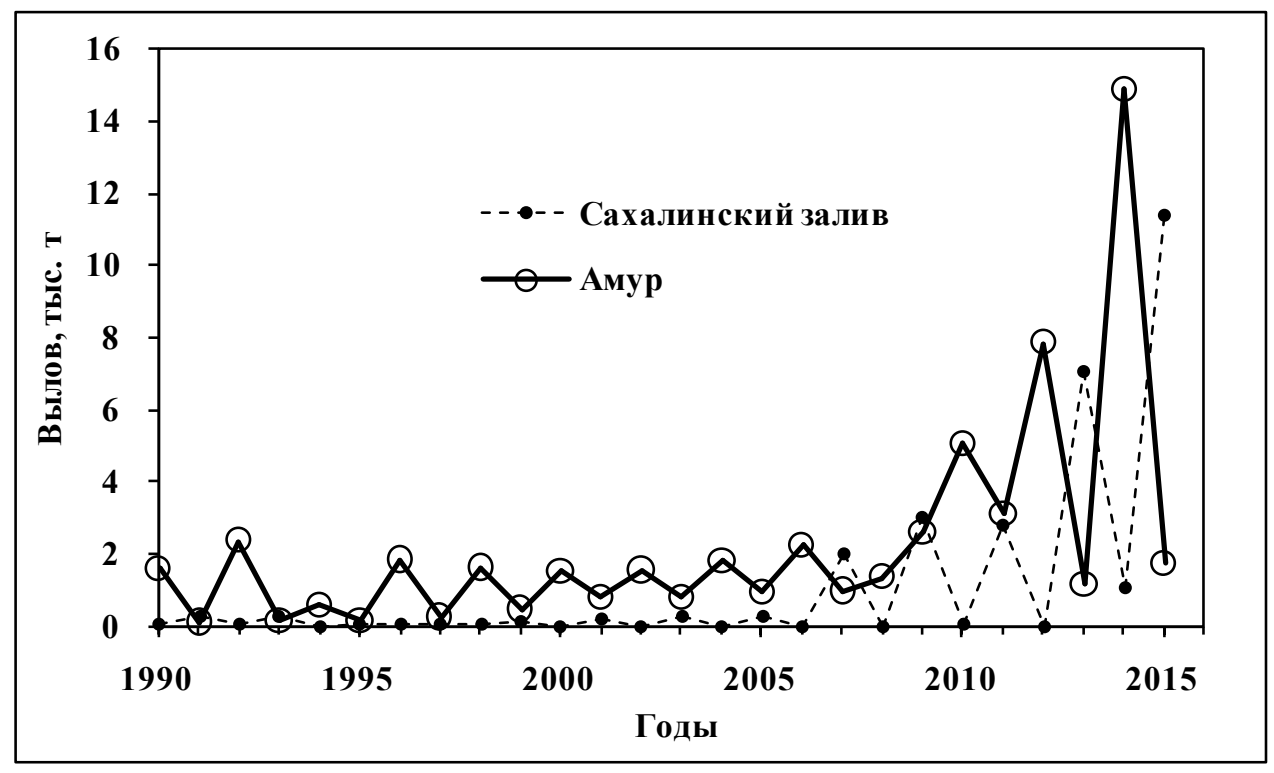

Рис. 12. Динамика уловов горбуши в материковой части Сахалинского залива и р. Амур

Fig. 12. Dynamics of the pink salmon annual landings $\left(10^{3} \mathrm{t}\right)$ at the mainland coast of the Gulf of Sakhalin and in the Amur

В Шантарском море лед может держаться до середины лета, и, вполне вероятно, малопригодными для воспроизводства горбуши являются не реки района, а именно прибрежье, поскольку известно, что скат молоди под лед снижает ее выживаемость (Гриценко и др., 1987; Карпенко, 1994, 1998). Но рост температуры воздуха в северовосточной части Евразии во второй половине прошлого века и в начале текущего сопровождается уменьшением площади льда в Охотском море (Oshima, McNeil, 2010). По-видимому, раньше стали образовываться и полыньи в устьях рек, впадающих в заливы Шантарского моря, что теоретически должно увеличить выживаемость мальков горбуши в раннем морском периоде жизни.

Не исключено, что направление прибрежных течений Охотского моря (http://platetectonic.narod.ru/0oxot3.png), несущих воды крупных рек-ориентиров с севера на юг, способствовало формированию путей миграции горбуши в Шантарское море в противоположном направлении - с юга, вдоль материкового прибрежья Сахалинского залива, а потепление - увеличению ее численности. По крайней мере, об этом свидетельствуют растущие уловы в Сахалинском заливе (рис. 12), которые не могут быть обеспечены воспроизводством местной рыбы и миграцией амурской или сахалинской. Учитывая, что уловы горбуши в Сахалинском заливе (группировки Коль, Чкалов) коррелируют с уловами в районе северо-западного Сахалина (см. рис. 2), можно предположить, что в сахалинских уловах присутствуют и рыбы Шантарского моря, но, вероятно, их вылов ощутим лишь по урожайным для Охотского моря нечетным годам.

Однако нарушения правильности чередования уловов горбуши четных и нечетных лет характерны и для других сахалино-курильских группировок. По-видимому, острова являются естественным ориентиром, барьером и местом вылова многих стад материкового происхождения. В случае отклонения трасс миграции горбуши за пределы досягаемости орудий лова (в настоящее время - 2 км от берега) уловы сахалинских рыбаков должны уменьшаться. При этом по нечетным годам должны увеличиваться уловы южной материковой охотоморской горбуши, по четным - амурской и приморской, у последних в настоящее время доминируют поколения четных лет.

По крайней мере этой гипотезе не противоречат результаты рекордных уловов горбуши в Сахалинском заливе в 2015 г., а также в подзоне Приморье и в Амуре в 2016 г. О том, что сверхмощный подход амурской и приморской горбуши в 2016 г. не 
является результатом стреинга, свидетельствует относительно слабый ее заход в р. Тумнин, где в 2014 г. численность производителей была недостаточной для обеспечения хорошего возврата.

\section{Выводы}

Полученные результаты позволяют заключить, что горбуша Амура и Амурского лимана мигрирует к родным рекам из Охотского моря через районы промысла северозападного Сахалина. Доля транзитной горбуши в уловах в данном районе составляет около $70 \%$, доля аборигенной - около 30 \%. Среднемноголетняя доля аборигенной горбуши в островных уловах в районе северо-западного Сахалина составляет менее $10 \%$ от ее вылова в Амуре.

Небольшая часть амурской горбуши мигрирует к нерестилищам близ материкового прибрежья Сахалинского залива. Ее влияние на улов в этом районе становится заметным лишь при очень мощных подходах, характерных для четных лет.

Кроме горбуши амурской группировки в районе северо-западного Сахалина может вылавливаться горбуша, мигрирующая в реки материковой части Сахалинского залива и, вероятно, Шантарского моря.

Рекордные уловы горбуши в материковом прибрежье Сахалинского залива в 2015 г., а также амурской и приморской горбуши в 2016 г., помимо хорошей выживаемости рыб, вероятно, связаны с уменьшением уязвимости материковой горбуши для сахалинских промыслов.

\section{Список литературы}

Беспалов Н.П. Уловы рыбы в водах Амурского бассейна : отчет о НИР / ХфТИНРО. Ч. 1. № 282. — Хабаровск, 1957a. — 17 c.

Беспалов Н.П. Уловы рыбы в водах Амурского бассейна : отчет о НИР / ХфТИНРО. Ч. 2. № 283. - Хабаровск, 1957б. — 24 с.

Гриценко О.Ф., Ковтун А.А., Косткин В.К. Экология и воспроизводство кеты и горбуши : моногр. - М. : Агропромиздат, 1987. — 166 с.

Енютина Р.И. Амурская горбуша (промыслово-биологический очерк) // Изв. ТИНРО. 1972. - T. 77. - C. 3-126.

Канзепарова А.Н., Подорожнюк Е.В., Козлова Т.В., Пономарев С.Д. Итоги лососевой путины и оценка запасов лососей в Хабаровском крае в 2013 г. // Бюл. № 8 реализации «Концепции дальневосточной бассейновой программы изучения тихоокеанских лососей». - Владивосток : ТИНРО-центр, 2013. - С. 83-90.

Карпенко В.И. Методические аспекты оценки смертности камчатской горбуши в ранний морской период жизни // Изв. ТИНРО. - 1994. - Т. 116. - С. 152-162.

Карпенко В.И. Ранний морской период жизни тихоокеанских лососей : моногр. - М. : ВНИРО, 1998. - 165 с.

Новомодный Г.В. О направлениях миграций лососей рода Oncorhynchus в Амурском лимане // Чтения памяти Владимира Яковлевича Леванидова. - Владивосток : Дальнаука, 2003. - Вып. 2. - С. 484-499.

Яновская Н.В., Сергеева Н.Н., Богдан Э.А. и др. Уловы тихоокеанских лососей : моногр. - М. : ВНИРО, 1989. - 213 c.

Oshima O.N., J. McNeil. Air temperature and sea ice // PICES Special Publication. № 4. Marine Ecosystems of the North Pacific Ocean 2003-2008. — Sidney : Institute of Ocean Sciences, 2010. - P. 273-275.

Поступила в редакциюю 20.06.16 г. 